Portland State University

PDXScholar

\title{
From Brotherhood and Unity to Fratricide: Propaganda in Former Yugoslavia
}

Jelena H. Grove

Portland State University

Follow this and additional works at: https://pdxscholar.library.pdx.edu/honorstheses Let us know how access to this document benefits you.

\section{Recommended Citation}

Grove, Jelena H., "From Brotherhood and Unity to Fratricide: Propaganda in Former Yugoslavia" (2018). University Honors Theses. Paper 510.

https://doi.org/10.15760/honors.515

This Thesis is brought to you for free and open access. It has been accepted for inclusion in University Honors Theses by an authorized administrator of PDXScholar. Please contact us if we can make this document more accessible: pdxscholar@pdx.edu. 
Running head: FROM BROTHERHOOD AND UNITY TO FRATRICIDE: PROPAGANDA IN FORMER YUGOSLAVIA

From Brotherhood and Unity to Fratricide: Propaganda in Former Yugoslavia

by

Jelena H. Grove

An undergraduate thesis submitted in partial fulfillment of the requirements for the degree of Bachelor of Arts

in

University Honors

and

International Studies - Europe

Thesis Advisor

Evguenia Davidova

Portland State University 


\begin{abstract}
The dissolution of Yugoslavia has become a textbook example of the power of propaganda in times of war. The former president of Serbia, Slobodan Milosevic, is famed for "stirring the pot" in Yugoslavia and is in many accounts uniquely antagonized for his role, while that of his counterpart, Franjo Tudjman of Croatia, is often overlooked. This thesis will give an overview of both sides' propaganda tactics (monopolistic control, historical revisionism, and appeals to emotions/anxiety) during roughly the years 1987-1992, which will cover their rises to power (1987-1990) and the beginning of the Wars of Yugoslav Succession (1991-1992). The aim of this paper is not to equate culpability, but rather to shed light on and contextualize, in relation to each other, the propaganda that was one of the central factors in the mobilization of Yugoslavia's two largest republics.
\end{abstract}




\section{Table of Contents}

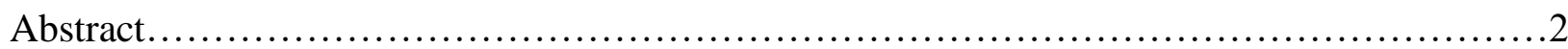

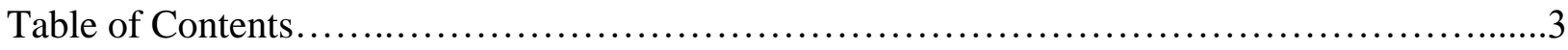

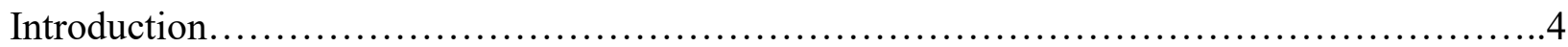

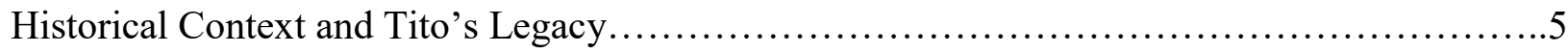

Rise of Slobodan Milosevic $(1987-1990)$.................................................

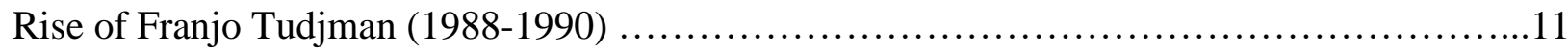

Serbian Mass Media $(1990-1992)$..................................................

Croatian Mass Media $(1990-1992)$................................................. 16

Discussion.................................................................... 18

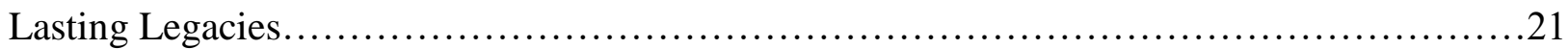

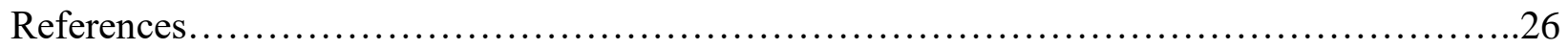


In no other situation can one find more allusions to ancient hatreds and more attributions to hostility as a central factor explaining the barbarity and inhumanity of the conflict - weekend warriors and paramilitaries, neighbours against neighbours, systematic slaughter of civilians and ethnic cleansing as state policy. It was indeed a bloody disintegration. - Dusko Sekulic, 2007, p. 799

\section{Introduction}

The violent collapse of Yugoslavia in 1991 was the result of myriad economic, political and social factors that have been the subjects of extensive academic discourse and debate over the last two decades, as the epigraph above attests. The mass media's role in mobilizing the country's various ethnic constituents is generally regarded as being one of the most salient aspects of the conflict. Yugoslavia was notorious for its use of propaganda throughout its existence, once as an instrument of "Brotherhood and Unity" under Tito and later of divisive ethnonationalist politics under Serbia’s Slobodan Milosevic and Croatia’s Franjo Tudjman. It was their nationalist goals, which at the time were diametrically opposed (Serbia for territorial expansion and Croatia for independence) that would come to dictate media output and tremendously influence public opinion in the years leading up to and during the conflict.

The former president of Serbia, Slobodan Milosevic, is famed for "stirring the pot" in Yugoslavia and is in many accounts uniquely antagonized for his role, while that of his counterpart, Franjo Tudjman of Croatia, is often overlooked. This thesis will give an overview of both sides' propaganda tactics (monopolistic control over media, historical revisionism, and appeals to emotions/anxiety) during roughly the years 1987-1992, which will cover their rises to power (1987-1990) and the beginning of the Wars of Yugoslav Succession (1991-1992). I will begin with history: first, I will provide historical context for Yugoslavia, then give a brief 
overview of Tito-era rule and propaganda. Second, I will discuss Milosevic and Tudjman's propaganda tactics in two sections: first the years preceding (1987-1989) and second during (1991-1992) the Yugoslav Wars. This division is necessary to show how ethnonationalist propaganda served first Milosevic and Tudjman's rises to power, then their countries' roles in the conflict. Next, the paper will discuss the commonalities between Milosevic and Tudjman's tactics, and will conclude with a discussion of the legacies and lasting ramifications of the Yugoslav Wars together with Serbia and Croatia's wartime mass media.

I use two terms throughout this paper that are necessary to first define here. I chose to rely on Eko Lyombe's (2002) working definitions as they are context-specific to propaganda used in the context of ethnic conflict. Firstly, ethnonationalism - if nationalism is the desire for congruence between the nation and the state, then ethnonationalism is the desire for congruence between the nation, the ethnic grouping (which includes heritage, religious and cultural aspects of identity), and the state (Lyombe, 2002). For instance, Croatian ethnonationalism encompasses Croatian heritage, Roman Catholic faith, Latin alphabet, Croatian culture(s), and the political borders within which ethnic Croats reside. Propaganda can be defined as a struggle for control of minds through control of communication infrastructure by which public opinion is influenced, swayed, and manipulated (Lyombe, 2002).

Yugoslavia is a country with six republics, five nations, four languages, three religions, two alphabets, and one Yugoslav— Tito. - Gary Bertsch, 1977

\section{Historical Context and Tito's Legacy}

Yugoslavia came into existence at the end of WWI, where the South Slavic remnants of the Austro-Hungarian, Byzantine and Ottoman empires converged as one multiethnic political 
entity. The South Slav tribes were historically and linguistically connected, but they were still culturally and ethnically separate. These groups eventually became the nations that would comprise the "pan-Slavic" state: Croatia, Slovenia, Bosnia and Herzegovina, Serbia (and its two provinces Kosovo and Vojvodina), Montenegro, and Macedonia. The competing imperial legacies resulted in the notoriously confusing and fragmented cultural bases that made up Yugoslavia (and traversed her porous borders): seemingly infinite linguistic dialects, uneven economic development, distinct cultural traditions, Latin and Cyrillic orthographies, and three major religions: Roman Catholic, Orthodox Christian, and Islamic faiths (as well as their differing social, economic and political dimensions/ systems).

After WWII, in 1945, the country was reborn as the Socialist Federal Republic of Yugoslavia (SFRY) under the leadership of Marshal Josip Broz Tito (1944-1980). His regime was built on the idea of "Yugoslavism," which was premised on social unification, political and economic centralization, and the development of a supranationalistic Yugoslav identity. "Brotherhood and Unity" was the proverbial slogan of the Communist Party of Yugoslavia-- it represented the Titoist doctrine present in his policies, rhetoric, and pan-Slavic vision for the country. Titoism (Yugoslavism) postulated that class identity and pan-Slavism were to transcend the "traditional" forms of identity extant in Yugoslavia- ethnic, religious, regional, and otherwise-- in order to live harmoniously in a non-aligned, pan-Slavic space (Volcic, 2007). In this view, each constituent republic was considered a part of the Yugoslav whole, and its mixture of ethnicities and national cultures was what made it so special. Tito, with the help of the Yugoslav League of Communists (LCY) within each Yugoslav federation, built upon "this ingrained sense of national identity in each of the republics, allowing them to foster a sense of identification with each republic within the context of belonging to an overarching Yugoslav 
state," (Volcic, 2007). It can be said that, for the most part, ethnic relations were generally good during the Tito years, despite great differences in economic development and disagreements over economic policy. After all, each republic had recovered significantly since World War II.

Notwithstanding the more or less peaceful ethnic relations under Tito, "it became increasingly apparent to the leadership that the former ethnic attachments to national cultures, traditions, and interests were not to be easily dissolved," (Bertsch, 1977). Furthermore, many national groups (but especially Croats) considered Tito’s centralist policies threatening and culturally repressive. As per his legacy as the "benevolent dictator" there were many unsavory aspects of Tito's regime, most of which would later be adopted by Milosevic and Tudjman: total monopoly over mass media and communications, censorship and repression of intellectual dissent, clandestine measures and even force to dampen what it considered nationalistic sentiments (Cohen, 2000; Silber \& Little, 1997). One poignant example is Tito’s effort to quell a Croat nationalist movement in 1971-- by dissolving the Croatian cultural organization Matica Hrvatska, firing its members that served Tito in the LCY, and cancelling 100 Croat nationalist publications (Lampe, 2000). In a seemingly counterintuitive effort to prevent more of such uprisings and to assuage ethnic tensions across Yugoslavia, Tito signed a number of sweeping federalization measures that restructured each republic's political domain and allowed them more control over their own affairs, and afforded them more cultural liberty. By the early 1970s Yugoslavia more closely resembled a confederation rather than a unitary state (Cohen, 2000).

In 1974, the final wave of federalization measures meant that each of the six republics of Yugoslavia had its own distinct education system, media system, central bank, and more or less autonomy over its own political and economic affairs. One of the last common threads in Yugoslavia was the leadership and cultural legacy of Tito, who died in 1980. He left a haphazard 
plan for Yugoslav state rule in his wake: rotating presidency. The void left by President Tito was ultimately filled with the divisive tactics of Serb and Croat nationalists as "the mainstream socialist Yugoslav rhetoric of the non-aligned movement and brotherhood and unity were, from the mid-1980s onwards, increasingly replaced by the rhetoric of national identities," (Volcic, 2006). Slobodan Milosevic of Serbia eagerly employed rhetoric of Serbian national identity, among other propaganda strategies, as the next section will discuss.

Realizing that Kosovo's political problems reflected the feeling of abandonment fostered in Serbs and Montenegrins and that these problems had become psychological problems, Milosevic touched on something that was a taboo topic for many years: Serbian national pride. - Agneza Bozic-Roberson

\section{Rise of Slobodan Milosevic (1987-1990)}

There existed a high degree of ethnic tension in the years following Tito's death, and the media played a crucial role in the manipulation of ethnic sentiments and mobilization of ethnic constituents, particularly in the late 1980s. These are perhaps best exemplified by the notorious tactics of the head of the Serbian League of Communists -- later president of Serbia -- Slobodan Milosevic, during his rise to power. Stepping out of the shadows of the Communist Party, his first significant media triumph came in 1987, which effectively launched him into the public eye and into power two years later (Silber \& Little, 1997). Political tensions had been high in the Kosovo province for some time, as Albanian separatist aspirations threatened Serbian positions of power (and, according to Serb media, the Serbian minority population residing there). In this instance, the Serbs had accused the Albanians of harassment in hopes of eliciting a response from their government, which was successful (Bozic-Roberson, 2005). Milosevic, at the time a 
member of Serbia's communist party (the LCY), was delegated the task of addressing the Serbian and Montenegrin minority population in Kosovo Polje.

In response to the massive protests and street violence that erupted between Kosovar Serbs and Albanians, Milosevic delivered a speech in April of 1987 at Kosovo Polje that would prove to be one of the most defining moments of his political career. The town was conveniently located at an ancient historical site that was the object of medieval Serbian lore: the legendary Serbian defeat by the Ottomans that took place there six centuries prior, an event that formed basis of the Serbs' cultural claim to the "sacred" territory of Kosovo-- despite its 90\% Albanian Muslim majority (Lampe, 2000). Milosevic's key success was in his use of the media to cover the speech: first by editing out scenes of Serbs throwing rocks to provoke police officers (successfully) to make it look like Albanian police were the aggressors, and second by ensuring the event be broadcasted country-wide on TV Belgrade instead of local news stations (Volcic, 2006; Bozic-Roberson, 2005). In other words, the ostensible aggression against the Serb minority and Milosevic's "heroic" response would be seen and heard by all Serbian minorities in Yugoslavia, many of whom had expressed complaints of discrimination by other ethnic groups for quite some time (Silber \& Little, 1997). In his address, Milosevic (1987) ordered the predominantly Albanian police to stop beating "the people," which sent the message that he would defend the Serbian people against aggression of any kind, not only in Kosovo but in all of Yugoslavia (Silber \& Little, 1997).

Almost instantly, Milosevic became a Serbian hero. His successful emotional appeal in the speech was the first in what would be an entire regime built upon the rhetoric of victimization, Serbian ethnic solidarity, and the politics of shared memory: "in Kosovo Polje Milosevic must have sensed an opportunity in seizing on Serbian fears," (Bozic-Roberson, 
2005). The legitimization of Serbian nationalism became the cornerstone of Milosevic's campaign for president. Following his address at Kosovo Polje, Milosevic began his consolidation of power, which resulted in a near media monopoly and the overthrow of the former Serbian president Ivan Stambolic. By the fall of 1987, Milosevic had seized control of influential media outlets including publications, radio and television stations, among them RTB (the major television station in Belgrade which had an all-Yugoslav broadcast), Politika (the most influential daily publication in Serbia), and three other major publications and newspapers (Bozic-Roberson, 2005). Milosevic disposed of virtually anyone that stood in his way: from party officials to journalists, editors, directors and actors, and replaced them with loyal members of his new party (Bozic-Roberson, 2005).

Riding the wave of popular unrest in the country, during 1988 Milosevic delivered passionate speeches at large-scale gatherings to mobilize Serbs all across Serbia proper. Attendance of the gatherings was massive (crowds as large as one million people) and widely televised. A multitude of grievances were aired, and Milosevic "reduced them all to manifestations of how Serbia and Serbs were suppressed," (Lampe, 2000). Furthermore, as the proposed solution, Milosevic "spoke only of the need for re-centralizing authority, first in Serbia and then across Yugoslavia" (Lampe, 2000). Re-centralization of Serbian authority was partially successful: in March of 1989 the provinces of Kosovo and Vojvodina officially lost their autonomy and were reabsorbed into Serbia, which meant that Milosevic effectively gained two more seats in the rotating presidency. With its celebrity platform and protection of Serbian national rights and interests, the Milosevic campaign undermined the already weak concept of Yugoslavism. 
It was unacceptable to Tudjman's HDZ, which saw in Serb autonomy, however mild, the negation of their over-riding objective - the founding of a Croatian nation-state. - Silber \& Little, 1997, p. 96

\section{Rise of Franjo Tudjman (1988-1990)}

The crisis in Kosovo and the rise of Milosevic intensified the wave of suspicion across the rest of Yugoslavia, which was especially pronounced in Slovenia and Croatia. Political and economic turmoil of the late 1980s made existing ethnic divisions more hostile and new political leadership more urgent: the country-wide party, the League of Communists, had dissolved, unemployment rose, living standards fell as average salaries decreased by $24 \%$, inflation jumped from $250 \%$ to $2500 \%$, and food shortages were common (Cohen, 1995). The state of the economy strained regional relations and intensified the public's awareness of the imbalances that had existed for decades — the markedly more developed Slovenia and Croatia resented their revenues from tourism being sent to finance what they believed were corrupt projects in Belgrade (Lampe, 2000). It was clear that the future of Yugoslavia was precarious, and moreover that "the economic discontent of the 1980s became closely intermingled with burgeoning ethnoregional nationalism," (Cohen, 1995). Such nation-forward leadership materialized in the likes of Franjo Tudjman, a former Yugoslav communist party member and JNA army general who later became a nationalist historian and eventually president of Croatia.

Like Milosevic, Tudjman established his own political party in 1989, called the Croatian Democratic Union (HDZ), which began as a reconstitution of loyal former communist dissidents whose allegiance was now with Croatia alone, and conveniently financed by wealthy Croatian emigres and exiles from the Tito years (Cohen, 1995; Silber \& Little, 1997). The HDZ was formed on the basis of Croatian sovereignty and liberation from Yugoslavia's long-time capital 
in Belgrade. On economic matters, the HDZ was decidedly pro-privatization, which added another dimension to its attempt to distance Croatia from Serbia. At the core of Tudjman's party was the goal of a unified Croatian state that would finally attain its "historical" aspirations for independence that had their roots in their "1000-year culture deprived of statehood" and former domination by the Austro-Hungarian empire (Silber \& Little, 1997; Cohen, 1995). The idea of a Croatian nation-state (which the media called "the thousand-year dream of all Croats") was what made HDZ particularly attractive to Croats who resided in Serb-majority territories in Croatia's southern periphery (known as the Serbian Krajina), as they had long been dissatisfied with Serbia's dominance of high-level positions in the military and overrepresentation in local and federal government (Cohen, 1995; Lampe, 2000).

Tudjman gratuitously employed victimization rhetoric that pandered to such qualms. In speeches and interviews, "Tudjman did not mince words about his belief that under communist rule the Croatian people had suffered ethnic discrimination owing to the disproportionately large number of Serbs occupying posts in Croatia," (Cohen, 1995). He wanted to emphasize the idea that Croatia had long been the victim of oppression by outside powers: Austria-Hungary, Tito's Yugoslavia, and now Milosevic's Serbia. Moreover, Milosevic's consolidation of power in Kosovo and Vojvodina and the unrest surrounding it worked to Tudjman's advantage in his campaign for president, as these events instilled fear in many Croats and "gave credence to those who demanded that Croatia should abandon Yugoslavia in order to get out from under the Serbian heel," (Silber \& Little, 1997). The uprisings to the east and threats of Serbian domination provided Franjo Tudjman with a sound justification for the use of ethnonationalism in his propaganda campaigns that would prove crucial for his ascent to the Presidency and for the eventual mobilization of the Croatian people. 
Over the course of his campaign, Tudjman used his platform and title of historian to strategically "spread the truth about Croatia," (Ugresic, 1994). Among these "truths" were the assertions of Croatian victimhood as mentioned above, and of Serbia's misrepresentation of Croatia's history, especially with regards to World War II. For example, Tudjman claimed the Serb communists had far exaggerated wartime atrocities committed by the Nazi collaborationist Independent State of Croatia (NDH) of the WWII period: the generally accepted death count (of Serbs, Jews, and Roma) at Croatia's Jasenovac concentration camp was around 100,000 (some estimates go as high as 700,000), but Tudjman maintained that no more than 60,000 people had been killed in all of Croatia in that period (Silber \& Little, 1997). These claims appealed to nationalist extremists and the exiled war criminals who were invited back to Croatia by Tudjman and who would contribute greatly to the establishment and success of the party (Lampe, 2000; Silber \& Little, 1997). With the help of these nationalist emigres, the HDZ rapidly came to dominate the seats in the Croatian parliament, or Sabor, and its influence quickly extended to key Croatian institutions from which Serbian and pro-Yugoslav communists were purged, including of course, the mass media.

Once unleashed, nationalism in Yugoslavia set on collision course the two largest nationalities, the Serbs and the Croats. - Anthony Oberschall, 2000

\section{Serbian Mass Media (1990-1992)}

By 1990, the independent press in Serbia was virtually non-existent, and was replaced with nationalist newspapers beholden to Milosevic's control (Lampe, 2000). The rise of Franjo Tudjman and the omission of any mention of Serb minority rights in the new Croatian constitution incited fear among the Serbian minority living within Croatia's borders and provided Serbian media with ample material; they wasted no time in associating Croatian independence 
under Tudjman with the Ustasha movement from fascist Independent State of Croatia (NDH) of the 1940s (Silber \& Little, 1997). Furthermore, the return of the emigres to Croatia made the Serbian portrayal of the HDZ's goals even more convincing, especially among the nervous Serb minority population living in the Srpska Krajina region within Croatian borders. To the nearly quarter of the Serbian population living outside of Serbia proper, the media's resurrection of WWII trauma further legitimized both Slobodan Milosevic's appeal as "protector" of the Serbian nation, and eventually, use of force against the nefarious "other" (Cohen, 1995).

Unrest and paranoia grew into open rebellion across Srpska Krajina at the end of 1990 and into 1991. The Krajina Serbs successfully recruited over 30,000 civilian volunteers and began receiving substantial military aid from the Yugoslav Federal Army (JNA) and from Belgrade itself (Lampe, 2000). They began staging what were effectively small-scale coups of police and post offices in towns across the eastern part of Croatia, emboldened by rhetoric from Belgrade and with the support of Milosevic and the entirety of the "Serb nation," (Silber \& Little, 2007). Eventually, the rebels declared the region as separate from Croatia, and it was soon recognized by Belgrade officially as the Serbian Autonomous Region of Krajina. When Croatian forces moved to reclaim territory, the Serbian media called it "warmongering" and an attack on “the Serbian nation," which warranted retaliation (Silber \& Little, 1997). Radovan Karadzic, a prominent Serb politician (conveniently, perhaps, trained in psychiatry) publicly addressed the Croatian "threat" in the region by announcing that "the Serbs are endangered again... This nation well remembers genocide [in World War II]. Those events are still a terrible living memory. The terror has survived 50 years," (as cited by Oberschall, 2000, p. 989). This kind of emotional reminder of Croatian atrocities and Serbian victimhood struck a chord in the turbulent Krajina, where it served to justify rebellion, and later violence, in the name of self-defense. 
State-run broadcasting Radio Television Belgrade (RTB) and daily Politika portrayed Albanians as terrorists, Croatians as Ustashas, and Bosnians as vengeful Muslim extremists who threatened the Serbian nation (Volcic, 2006). This was all in an effort to portray Serbs as "tragic and blameless victims to an international conspiracy to destroy the Serb people and their homeland," (Bozic Roberson, 2005). Moreover, it stressed the importance of military protection of Serbs in Krajina-- not only by arming civilians, but by gaining the favor of the JNA, which eventually succeeded (Silber \& Little 1997). RTB's coverage of Milosevic's frequent solidarity gatherings was another useful weapon in the mobilization of Serbs both within and outside of Serbia proper. One of Zala Volcic's (2006) interviewees had attended these gatherings, and she noted that the media's portrayal of them was shockingly convoluted; coverage of the meetings was constantly repeated on television and was supplemented with nationalist insignia, passionate chanting, overstated degrees of violence, inflated crowd sizes, and full of effects that generally aggrandized the situation and incited sympathy for the "plight" of the Serbs (p.318).

The severity of Serbian propaganda's exaggerations, misrepresentations, and fabrications intensified over the course of the 1991. While Croatian media diminished the number of Serbian deaths at the Jasenovac concentration camp (less than 60,000), Serbian media inflated them, with claims as high as 700,000 (Oberschall, 2000). Rape and genocide discourse dominated in the press, and such news stories spread fear of extinction among Serbs everywhere (Oberschall, 2000). Stories in influential Serbian daily newspapers (like Vjesnik, Borba) reminded the Serbian public of the very real brutality of the Croatian Ustashe during WWII, and more stories were published about present-day Croatian National Guardsmen emulating their atrocities on a massive scale: shelling entire villages, ethnic cleansing, church burning, stories of rape, of torture, and of skinning and burying Serbian women and children alive (Brock, 2005). Images 
were manipulated and massively circulated in the press to corroborate the claims of atrocities against the Serbs: famously, a $19^{\text {th }}$-century painting titled “Orphan at Mother's Grave”, was edited and circulated as a photograph in a daily Serbian newspaper that claimed it was a Serbian boy mourning the death of his entire family, who were supposedly killed by Bosnian Muslims. Neither the television, the radio, nor the press showed the atrocities committed by Serbs during the war (Brock, 2005), and silenced dissident voices at virtually every level (Cohen, 1995). When students planned a protest against Serbian media control, it was promptly shut down by the Interior Ministry (Lampe, 2000).

From day to day among the mass of people the fear of Serbian aggression spread, and also the readiness to stand behind those politicians promising to withstand it.

- Dusan Bilandzic, 1999, as cited by Sekulic p. 808

\section{Croatian Mass Media (1990-1992)}

The rebellion in the Krajina region provoked a strong backlash from Franjo Tudjman and the HDZ, who vowed to reclaim the lost territory and not allow "a single inch" of Croatia's border to be taken (Silber \& Little, 1997). The events and ensuing media coverage polarized public opinion still further, and made Tudjman's hardline stance more popular among more moderate Croats who now saw the unfolding chaos as proof of a legitimate Serbian threat (Cohen, 1995; Silber \& Little, 1997). Moreover, although at this point open war hadn’t yet begun, it was becoming increasingly apparent that the JNA was in fact beholden to Belgrade (having been the military arm of the Communist party since its inception and disproportionately high Serbian participation) and ready to defend the Serbs in Krajina against Croatian shows of force (Lampe, 2000). Thus, the stakes were high for Tudjman to mobilize enough support for the 
reclamation of Krajina, and ultimately for Croatian secession from Yugoslavia, in the face of both Serbia and the Yugoslav Federal Army.

To Croatians, the prospect of a union between the Milosevic regime and the Yugoslav army was terrifying, as it seemed to confirm Franjo Tudjman's campaign warnings of Milosevic's insidious and conspiratorial plan to create a "Greater Serbia" under the guise of reformed communist state-building, for which the declaration of the Serbian Autonomous Region of Krajina in 1991 was the precedent (Lampe, 2000). Moreover, it legitimized Tudjman's efforts to "protect" the Croatian state against the "enemy within" at all costs-- first by reorganizing administrative and police systems within the Krajina region to replace Serbs with HDZ loyalists at virtually all levels of government, and secondly by retaking, with force if necessary, towns and offices already occupied by Serb rebels (Silber \& Little 1997; Cohen, 1995).

In one of the first conflicts before open war, a failed reconnaissance mission in Borovo Selo resulted in the deaths of 12 Croatian police officers and inspired a propaganda firestorm. State media capitalized on the event, allowing it to mobilize the remaining support it needed, both domestic and foreign. The media campaign that followed villainized the Serbs much like the Serb media had villainized Croats past and present; according to Anthony Oberschall (2000), the Croatian press resurrected painful memories of the 1945 massacres at Bleiburg "with highly inflated figures on the ethnic killings" (p.990). Radio and television used such memory politics to instill fear, disguised as warnings for the present: depictions of the "Chetnik terror" (the Serbian guerilla WWII counterpart to the Ustashe) abounded, and Serbs were referred to as usurpers, murderers, and terrorists (Lampe, 2000; Bozic-Roberson, 2001). Indeed, as Silber \& Little (1997) note, the campaign "pandered to the worst excesses of Croatian 'Serbophobia,", 
(p.142). To make matters worse, a new slogan emerged - "Croatia for Croatians only" - that very clearly echoed propagandistic slogans from Nazi Germany. For the new national flag of Croatia, Tudjman symbolically chose to eliminate the communist 5-pointed star and replace it with a sahovnica shield, a checkerboard pattern taken directly from the flag of the NDH.

Despite its neo-fascist undertones, Croatia's mass media was much more successful than Serbia's in garnering the support of the international community, mainly the West (Lyombe, 2002). Militarily the Croatians were outnumbered, so Tudjman had to rely on the help of foreign powers (i.e. NATO, the US, and Germany) to gain an edge against the combined forces of the Yugoslav army and Serbian paramilitaries. To win the Western media's sympathy, Croatia had to prove that the Croats, not the Serbs, were really the victims all along. Tudjman was able to produce a new image of Croatia in the eyes of the West vis-à-vis the establishment and financing of both public and private institutions (such as the Ministry of Information, and the Croatian Anti-Defamation League) that were designed to create and disseminate images of Croatia and its history in a more positive light for international consumption (Ugresic, 1994, Bozic-Roberson 2001). They did so domestically as well; according to Dubravka Ugresic (1994), the Ministry of Information modified Croatian history textbooks to such a degree that they hardly resembled the Yugoslav textbooks from just a few decades prior (p. 39).

How is it that when the media unleashed the war of words and symbols before the war of bullets, so many believed the exaggerations, distortions and fabrications that belied their personal experiences? - Anthony Oberschall, 2000, p. 987

\section{Discussion}


Many Western analyses tend to focus one-sidedly on the mass media and propaganda of Slobodan Milosevic, while minimizing those of Franjo Tudjman (Brock, 2005). Indeed, this fact is a testament to Tudjman's media successes, as enormous efforts were made by his regime to gain the recognition and sympathy of the West, which were ultimately granted (militarily, politically, socially). Nevertheless, as this literature review has shown, Slobodan Milosevic and Franjo Tudjman's rhetoric and mass media shared many key parallels, both in their rises to power and during the conflict. Indeed, some authors have even described their roles as “synergistic” and "symbiotic” (Lampe, 2000; Silber \& Little, 1997; Ugresic, 1994).

Due to an enduring lack of definitive and objective information (for reasons of fabrication and loss/destruction), it will likely always be unclear exactly the degree to which each side falsified and disseminated the "truth" in this period (Silber \& Little 1997). However, a few items are clear: both parties gained monopolistic control over their media institutions and were able to dismantle and censor opposition (moderates of their own nationality and nationalists from the "other"); both leaders used incendiary ethnonationalist rhetoric in their public addresses, which was successful in part because both leaders exploited legitimate fear that stemmed from severe economic and political imbalances rather than "primordial" ethnic hatreds; both countries' mass media (press, television, radio broadcasts) gratuitously employed victimization rhetoric and focused one-sidedly on the suffering of their own nation at the hands of the "other"; both parties engaged in historical revisionism (most importantly regarding WWII) in their rhetoric, their media, and their education systems (e.g. both rewrote textbooks and effectively created new "national truths" that are still being taught today); and both sought to distance themselves from the "other" culturally, vis-à-vis religion, cultural myths and orthography. 
There are a few key differences of note, however. Croatia targeted both domestic and international audiences with its propaganda campaigns, whereas Serbia targeted primarily the Serbian minority populations living in parts of Croatia and Bosnia, and also those residing within Serbia proper. Ultimately, Tudjman's success in swaying influential, wealthy emigres proved useful in his campaign to reshape the international community's perception and attitudes in favor of Croatia. Domestically, the return of the emigres to Croatia had a profound impact on political outcomes, particularly for the HDZ. As Ramet (2011) notes, there are many other key differences among the two regimes that are outside the scope of this paper, namely, structural differences, degrees of criminalization and corruption, political culture, and political economy, all of which has contributed to the rift between the two countries today (p 268).

Tito's federalization reforms of 1974 and death in 1980 provided a permissive enough framework and political climate within which Milosevic and Tudjman could maneuver to regulate their own media systems and dictate output. With no shortage of corruption on both sides, Milosevic and Tudjman were able to purge moderates and opposition from political, financial and educational institutions and replace them with loyal cronies, and furthermore were able to rewrite legislation allowing for their continued consolidation of power and systematic corruption under the guise of "state building." Franjo Tudjman was an outright nationalist. Slobodan Milosevic was a nationalist masquerading as a communist. Ultimately, both leaders contradicted themselves by publicly expressing devotion to their national causes while secretly engaging in meetings with one another to discuss the partition of Bosnia. These negotiations, if successful, would have deprived the war-torn country of the very rights that Tudjman and Milosevic had sought - and waged a war over - for their own people (Silber \& Little, 1997, p. 144). 
Since ethnic problems usually exist within the context of economic and political crisis, the leader has a choice whether to deal with the problems in the productive manner or to create fear and hate and direct major frustrations of his people against specific groups. - Agneza Bozic-Roberson, 2005, p. 396

\section{Lasting Legacies}

The UN's International Criminal Tribunal for the former Yugoslavia (ICTY) was established at The Hague in 1993 to deal exclusively with the indictment and prosecution of 161 individuals from all sides of the conflict. Charges against prominent leaders and politicians from across Yugoslavia included crimes against humanity, genocide, torture, rape, enslavement, destruction of property, embezzlement, and corruption (ICTY, 2009). While there is some discrepancy, as is commonplace with any "official” data regarding the former Yugoslavia, it is generally accepted that between 130,000-200,000 people died in the conflicts and over four million more were displaced (Lampe, 2000). The Yugoslav Wars have become notorious for their brutality, insidious use of propaganda, and large-scale human rights abuses, perpetrated in large part by Serbia, and to a slightly lesser extent by Croatia. Regarding the wars, one often hears expressions such as "neighbors turned on neighbors", "brothers killed brothers", and "families were ripped apart" to describe the nature of the ethnic violence in the region. Indeed, the now commonly used term "ethnic cleansing" was borne from the Yugoslav wars. These expressions are testaments to the depth with which the collective memory of past trauma plagued the minds of Yugoslav citizens - powerful enough to disintegrate interpersonal bonds of friendship, kinship, and shared culture (Ramet, 2013).

The conflict between Croatia and Serbia officially ended with the 1995 Dayton Peace accords, although unrest in the area persisted and violence reignited in Kosovo and Serbia as late 
as 1999. Serbia continued to suffer significantly after the conclusion of the fighting in Croatia and Bosnia; it descended into hyperinflation and its economy all but imploded after harsh sanctions and eventual military intervention by NATO and the United States (Lyombe, 2002). One year after the 1999 NATO bombing of Radio Television Serbia, Slobodan Milosevic was effectively ousted from the Serbian presidency and subsequently tried for war crimes at the ICTY. In March 2006, after five years of trial, Milosevic died of a heart attack awaiting the verdict in his Hague prison cell. Tudjman served as president of Croatia until he died of cancer in 1999. While Tudjman and Milosevic have been out of office now for almost twenty years, the propaganda machines of the two late leaders have both had lasting socio-political ramifications that endure to the present day.

While political relations between the two countries have no doubt improved overall in the last two decades, under the surface there are still pockets where nationalism dominates ideology and where resentment, ethnic intolerance and animosity are quite high. Sekulic et al. (2006) have argued that in fact, ethnic intolerance rose as a result of the war (rather than being the cause of the war) and has been "slow to dissipate" (pg. 797). According to Sekulic et al.'s research (2006), post-war ethnic intolerance has been especially present in rural, war-torn parts of Croatia and in urban parts of Serbia, which he attributes to a combination of the experience of war, demographic changes resulting in ethnic homogenization, lower rates of mixed marriages, and an upsurge in religiosity (p. 818). For example, between 1989-1996, the population of Croats residing in Croatia rose from $74.1 \%$ to $92.2 \%$, while Croatia's Serbian population fell from $12 \%$ to $3.1 \%$ over the same period (Sekulic, 2006). My own personal observation during extensive time spent in rural Croatia supports Sekulic's findings: much of my cohort of young Croats (I was born in 1992) - many of whom were born in bomb shelters and/or to traumatic early 
childhood life, raised in fear by devoutly Catholic parents who saw war firsthand - can hardly be described as progressive in their views of the Serbian "other" (and their parents even less so) in spite of updated school curriculum, two decades of peace and ostensibly more relaxed relations between the two states. There are many such anecdotes and news stories circulating today, but clearly, more scholarly research is necessary to measure how ethnic intolerance has actually changed in the last decade, with special attention to the new generation of young adults born during the conflict, and to areas that saw fighting, if there is to be any hope of reconciliation within these areas.

Now that the former republican borders have become international borders, ethnonationalism has transformed into patriotism, and the two states appear to be more culturally separate since the end of the war. The first and most obvious example of cultural separation is each country's adherence to separate religions, which becomes especially salient in the context of the strong association between religiosity and national identity in times of war (Sekulic, 2006; Djokic 2002). Pew Research Center reports that $84 \%$ of Croats identify as Roman Catholic while $88 \%$ of Serbs identify as Orthodox Christian (Mitchell, 2017). Intentional linguistic separation is also a source of cultural distance between the two- what was once called the Serbo-Croatian language has fragmented into Croatian and Serbian, depending upon one's political views. A third example of this separation can be seen in Croatian and Serbian mainstreams' opposing interpretations and commemorations of the same events. One of the more well-known occasions is that of Operation Storm, which took place August 4-7 of 1995, wherein Croatian forces retook the Krajina region and drove out a large proportion of the Serbian population residing there. In Croatia, August 5th is considered a commemoration of victory and independence and is 
celebrated as an official public holiday, while in Serbia the same day is one of solemn remembrance and mourning for those driven from their homes and/or killed.

As Sabrina Ramet (2011) has shown, the two countries' political paths diverged significantly in the post-war era, which has resulted in markedly different trajectories for the two countries over the last twenty years (p. 263). The issue of accession to the European Union is a good point of comparison of their progress (and lack thereof). Croatia received full candidate status for accession to the EU in 2004 and began amending its constitution according to EU standards in the early 2000s. Croatia introduced significant amounts of new legislation to tackle corruption, provide protections for minorities, establish and deepen separation of powers in government, indict war criminals, and introduce comprehensive media reform (Ramet, 2011). Furthermore, in 1999, Croatia implemented textbook reform in an attempt to correct the "ambivalent way in which the NDH was presented," although some Croatian scholars question the integrity of these efforts as they still tend to espouse one-sided beliefs in Croatian victimhood (Ramet, 2011; Ramet, 2013). Nonetheless, these reforms were the first of many that would gain Croatia the favor of the European community years later. Croatia officially entered the EU in 2013 as the $28^{\text {th }}$ member state.

On the other hand, Serbia was initially reluctant about joining the EU and particularly about adhering to its policy recommendations, as it has had a slew of unique obstacles to overcome before officially being granted candidate status in 2012. According to Ramet (2011), the continued subjugation of the Kosovo territory to Serbia's political domain, unwillingness to cooperate with the ICTY, and persistent, systemic corruption have contributed to its delays in obtaining candidate status (pg. 283). That is, owing in part to the dismal economic prospects that followed the conclusion of the war in Serbia, its government became deeply criminalized and 
reliant on black markets, an issue that, while certainly having improved in recent years, still plagues the country's development and political culture (Ramet, 2011). Nonetheless, the establishment of a Truth and Reconciliation Commission seems to be a step in the right direction, and widespread anti-corruption movements indicate that at least the people, if not their politicians, have an interest in a new post-Yugoslav peace. 


\section{References}

Bertsch, G. K. (1977). Ethnicity and Politics in Socialist Yugoslavia. The Annals of the American Academy of Political and Social Science, 433(1), 88-99.

doi:10.1177/000271627743300109

Bozic-Roberson, A. (2001). The politicization of ethnicity as a prelude to ethnopolitical conflict: Croatia and Serbia in former Yugoslavia (Doctoral dissertation, Western Michigan University) [Abstract]. Retrieved from http://scholarworks.wmich.edu/dissertations/1354 (UMI No. 1354)

Bozic-Roberson, A. (2005, January). Words Before the War: Milosevic's Use of Mass Media and Rhetoric to Provoke Ethnopolitical Conflict in Former Yugoslavia. East European Quarterly, 38(4).

Brock, P. (2005). Media Cleansing: Dirty reporting, Journalism and Tragedy in Yugoslavia (2nd ed.). Los Angeles: GM Books.

Cohen, L. J. (1995). Broken bonds: Yugoslavia's Disintegration and Balkan Politics in Transition (2nd ed.). Boulder, CO: Westview.

Djokic, D. (2002). The Second World War II: Discourses of reconciliation in Serbia and Croatia in the late 1980s and early 1990s. Journal of Balkan and Near Eastern Studies, 4(2), $127-$ 140. doi:10.1080/1461319022000021585

ICTY (2009). Updated Statute of the International Criminal Tribunal for the Former Yugoslavia. Retrieved from http://www.icty.org/X/file/Legal\%20Library/Statute/statute_sept09_en.pdf

Lampe, J. R. (2000). Yugoslavia as history: Twice there was a country. (2nd ed.). Cambridge: Cambridge University Press.

Lyombe, E. (2002). Bombs and bombast in the NATO/Yugoslav War of 1999: The attack on Radio Television Serbia and the laws of war. Communications and the Law,24(3), 1-45.

Mihelj, S. (2013). The Politics of Privatization: Television Entertainment and the Yugoslav Sixties, The Socialist Sixties: Crossing Borders in the Second World. Bloomington, IN: Indiana University Press.

Mitchell, T. (2017, May 10). Religious Belief and National Belonging in Central and Eastern Europe. Retrieved from http://www.pewforum.org/2017/05/10/religious-belief-andnational-belonging-in-central-and-eastern-europe/

Oberschall, A. (2000, November). The manipulation of ethnicity: From ethnic cooperation to violence and war in Yugoslavia. Ethnic and Racial Studies, 23(6), 982-1001. doi:10.1080/014198700750018388 
Ramet, S. P. (2011). Croatia and Serbia since 1991: An Assessment of Their Similarities and Differences. Journal of Communist Studies and Transition Politics, 27(2), 263-290. doi:10.1080/13523279.2011.564098

Ramet, S. P. (2013). Memory and identity in the Yugoslav successor states. Nationalities Papers,41(6), 871-881. doi:10.1080/00905992.2013.801419

Sekulić, D., Massey, G., \& Hodson, R. (2006). Ethnic intolerance and ethnic conflict in the dissolution of Yugoslavia. Ethnic and Racial Studies, 29(5), 797-827. doi:10.1080/01419870600814247

Silber, L., \& Little, A. (1997). Yugoslavia: Death of a Nation. New York: Penguin Books.

Snyder, J., \& Ballentine, K. (1996). Nationalism and the Marketplace of Ideas. International Security, 21(2), 5-40. doi:10.2307/2539069

Ugresic, D. (1994). The Culture of Lies. Index on Censorship, 23(1-2), 23-43. doi:10.1080/03064229408535635

Volčič, Z. (2006, September). Blaming the Media: Serbian Narratives of National(ist) Identity. Continuum, 20(3), 313-330. doi:10.1080/10304310600814177 